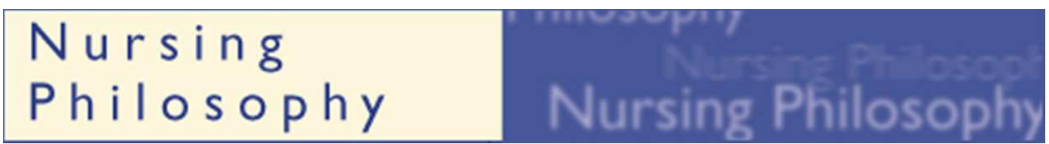

\title{
Bodily cleanliness in modern nursing
}

\begin{tabular}{|r|l|}
\hline Journal: & Nursing Philosophy \\
\hline Manuscript ID: & NUP-2011-0084.R1 \\
\hline Manuscript Type: & Original Article \\
\hline Keywords: & Discipline, Foucault, Modernity, Nursing Philosophy, Self-Care \\
\hline \multicolumn{2}{|l}{} \\
\hline
\end{tabular}

\section{SCHOLARONE $^{\text {m }}$ \\ Manuscripts}




\title{
Bodily cleanliness in modern nursing
}

\begin{abstract}
Why are bodily washing practices the way they are in nursing?

Michel Foucault argues that modern democratic societies discipline human bodies in accordance with political interests. In the extension of that argumentation we will show that bodily cleanliness in modern nursing may have been used as a disciplining tool. The first part of our discussion takes as its point of departure the second half of the $19^{\text {th }} /$ the beginning of the $20^{\text {th }}$ century, the period in which modern nursing emerged. At that time scientific theories on hygiene seem to have legitimized the political effort to produce a clean, pleasant-smelling, decent, obedient, and productive population. Doctors, nurses and teachers played important roles in the implementation of hygienic bodily washing practices. The second part of the discussion focuses on the Post War period. At that time humanistic needs theories seem to have legitimized political argumentation for independent patients who washed themselves if possible. Those who could not manage on their own, should, as far as possible, be washed by cheaper staff, so that nurses could concentrate on medical treatment. Finally we argue that present day bodily washing practices in nursing are in accordance with the norms of appearance and smell that arose in the second half of the $19^{\text {th }}$ and the first part of the $20^{\text {th }}$ century. We further argue that staff with little or no education perform much of the bodily nursing work. Self-care seems to be of interest only when it reduces public expenses.
\end{abstract}

Keywords: Cleanliness, baths, body wash, evidence, hygiene, needs, sanitation 


\section{Introduction}

At the end of the 1980ies I (first author) worked as a visiting nurse at the Churchill Hospital in Oxford. There I came in contact with a ward for older patients. Many of the patients suffered from major paralysis as a result of brain haemorraging. What was particular to this ward was that all patients had their whole bodies massaged twice a day with oils adapted to each individual, during the body wash routine. This was accompanied by music the patient appreciated. Often as sounds from nature. This way of caring for patients was a break with what I had seen in other areas of Churchill Hospital, a break with body wash as taught in Norwegian nursing, and a break with care as practised in Norwegian health institutions. I later started wondering how it could be that body wash as I knew it and had practised it, was as it was. Finding the answer to this proved difficult. In my search for explanations I came upon the French historian Georges Vigarello's study, arguing that the authorities in Western industrial societies have used bodily cleanliness as a disiplinary tool (Vigarello 1988). In what follows we will take a closer look at relation between bodily cleanliness in nursing and politics at the time of the birth of modern nursing, during the decades following World War II, and in our time.

\section{From ritualistic to modern hygienic cleanliness}

The nursing education and Western bodily cleanliness norms of our time emerged during the second half of the nineteenth century (Vigarello 1988: 224-225). To understand current bodily practises, we have to study the context that made the practices acceptable at a certain point in time (Foucault 1994: 225).

\section{$\underline{\text { Ritualistic cleanliness }}$}

Norway's first nursing school was established in 1868. At that time ordinary people generally washed their whole body once a year - at Christmas. Men who worked as farmers, fishermen, or in the woods did not wash every day. Women who were more in contact with water might wash hands and face on a daily basis. Although there were little every day washing, it was very important that everybody washed visible body parts on Saturdays. People did not wash for the sake of hygiene, but in preparation for entering into the presence of God and their fellow men. Such washing practices are well documented by Eilert Sundt, who is considered the first Norwegian sociologist (Sundt 1975/1869: 290-328). The general Swedish population seem to 
have shared this understanding of cleanliness at this time; farmers and their families smelled of the barn, fishermen smelled of fish, and they considered dirt a positive protection against frost and illness (Frykman 1994:131-221). Scandinavian people's cleanliness seems to have been in accordance with ordinary people's practices in England. In her textbook Notes on Nursing, from 1860, Florence Nightingale writes that she is upset that people are proud of not washing other parts of their bodies than hands, head and face (Nightingale 1997/1860: 136). Nightingale, who is considered the founder of modern nursing, was an upper class woman, and in the second half of the eighteenth century, the Establishment in industrialized societies seems to have disassociated themselves from poor farmers and workers by keeping clean. Cultivated people were encouraged to be hygienic and bathe every day (Frykman 1994: 131-221).

\section{$\underline{\text { Political context }}$}

Modern nursing emerged in England at a time when Western nations went from being traditionally agricultural to becoming modern industrialised societies (Nerbøvik 2004/1999: 20-94). Free competition, the new economic ideal, reinforced the class system. Factory owners and landowners became richer, while workers and landless farmers became poorer. As poverty was considered an expression of low morale, neither the wealthy, nor the government or the church, accepted responsibility for the needy. However, society needed a strong, healthy, compliant, and productive population (Schiøtz 2003, Moseng 2003). The English lawyer Edwin Chadwick was engaged to find out how to possibly reduce the costs associated with the illnesses and high mortality rates in the lower classes. His work resulted in an extensive documentation of the extremely bad living conditions of the lower classes in England. That changed Chadwick's view of poverty. From considering it a question of morals, he changed to claim that it was the social and material conditions that made people dirty, hungry, poor, and ill. He insisted on political action to improve the lower classes' living conditions, and started Sanitation Movement (Martinsen 2003/1989: 169-181).

\section{Modern, hygienic cleanliness}

Chadwick and Nightingale collaborated closely in Sanitation Movement (Sydnes 2001). They argued for drain systems, clean water, clean and airy streets, houses, clothes, and bodies. They claimed that improved sanitation and health legislation 
would be economically advantageous to society as a whole. The politicians did not listen to the Sanitation Movement until the death rates in the working classes became a real productivity threat and there was a danger of rebellion. The English health legislation of 1847 represented a breakthrough for Western sanitation (Martinsen 2003/1989: 169-181). Both the English health legislation and the worldwide popularity of the world's first textbook on nursing, Nightingale's Notes on Nursing from 1860, may have contributed to the spreading of the sanitary movement. Both texts are permeated with sanitation ideas.

Bodily cleanliness had a central place in the Sanitation Movement's argumentation, and poor people were encouraged to wash themselves in accordance with the hygienic norms for cleanliness prevalent in the more cultivated classes. During the $19^{\text {th }}$ century the hygienic miasma theory dominated the Establishment's understanding of cleanliness. According to this theory, dirt could prevent the exchange of oxygen and carbon dioxide through the skin, and dirt was also said to be dangerous because infectious particles could enter unclean places and become transformed into disease-producing miasma. After around1880, the theory of miasma gradually gave place to the theory of microbes. Cleanliness was considered an important tool for preventing both miasmas and microbes from causing illnesses (Schiøtz 2003: 25-78, Boge 2008: 25-29).

\section{Look clean}

If bodily washing practices in nursing were based on hygienic theories, we might expect nursing textbooks to advocate thorough and frequent washing of the parts of the body which accumulate the most dirt. However, the first Norwegian nursing textbooks, written in the period 1877-1901, do not do so (Nissen 2000/1877, Kaurin 1879, Waage 1901). On a daily basis it sufficed that the patients had their face and hands washed, their mouth cleaned and their hair brushed. Other parts of the body should only be washed on admittance to the hospital and then once a week, unless there were special reasons for doing so more often. This washing regime was not in accordance with hygiene theory. It was, however, largely in accordance with common people's ritual washing practices at the time, with their concentration on visible parts of the body (Sundt 1975/1869: 290-328). 


\section{Do not smell}

In 1911 the first Norwegian nursing textbook advocating daily washing of non-visible parts of the body was published. This textbook recommended that patients not only wash visible body parts every day, but covered parts as well, in areas with skin against skin, e.g. under arms, under breasts, the groin, around the anus and the genitals (Waage 1911/1901: 82). At first glance, this would appear to be in line with what is expected on the basis of microbe theory. However, there is little to suggest that these practices were based on such theory, among other things, because the chapter on micro-organisms in the textbook from 1911 is identical to the chapter in the first version from 1901. If the washing practices were based on microbe theory, we would expect the arguments for more comprehensive daily washing to have been included in the 1901 version. No new microbe knowledge was, however, included in the 1911 textbook. The chapter on microbes and the chapter dealing with bathing do not appear related in either version. It is more probable that the arguments for washing covered parts of the body were a result of diminished tolerance for body odour in Norway in the years around 1911. As we saw above, removing rubbish, introducing drain systems, access to clean water, clean and airy streets, houses, clothes and bodies were central to health legislation in Western countries in the second half of the nineteenth century. When dirt had been removed from streets, houses and clothes, the smell from less than clean covered parts of the body must have become insistent. The detailed washing instructions that appeared in the Norwegian nursing textbook in 1911 most likely reflect the official opinion on how bodies ought to be washed at that time, in order to reduce body odours.

\section{Detailed political regulations of the body}

Detailed regulations on how to use the body may, according to Foucault, have been used to govern the inhabitants in democratic societies. He uses soldiers as an example. From being brave, elegant and proud men, the soldiers became, in the second half of the nineteenth-century, a kind of material to be formed into a useful machine - into a body that was always service-minded. The same kind of body control became prevalent in hospitals, schools, and factories. The goal was to form the useful body without the use of violence, and this was done by focusing on details. Every detail was important and could be utilized politically. Optimal use of time 
became important, and good use of the body made good use of time possible. One had to intensify the use of every minute. Those who weren't effective were sanctioned, as were the impolite, dirty or obscene. In this way the normal, democratic population was formed (Foucault 1999/1977:125-201).

\section{Scientific legitimacy}

Science seems to have had an important role in legitimizing the formation of the democratic population. Foucault argues that individuals have been disciplined biologically by using scientific knowledge to legitimize politically expedient bodily practices (Foucault 1995/1976: 62-86). Hygienic theories are considered scientific knowledge. Foucault's argumentation may explain why there are chapters on microorganisms in nursing textbooks, although no connection is established between the scientific argumentation in those chapters and the washing norms that are advocated in other chapters in the same book. The scientific knowledge on microbes in the textbooks may only have been used to legitimize the modern norms of appearance and smell that became politically interesting towards the end of the eighteenth and the beginning of the nineteenth century. The detailed bodily washing instructions that appear in Norwegian nursing textbooks in the period 1877 - 1911, may have been part of the disciplining formation of democratic, civilized individuals.

Bodily cleanliness appears to gradually become a necessity in democratic societies, but it was at times difficult to convince ordinary people that they had to wash more often and detailed than they were used to. In order to get people to follow the political arguments, doctors argued for causal connections between dirtiness and such illnesses as leprosy. Sundt's studies on cleanliness did not support such argumentation. He found that the level of cleanliness might be high in areas with much leprosy, compared to areas with little or no leprosy. He further claimed that ordinary people would follow the established norm for cleanliness if they had better living conditions. When he did his study on cleanliness in 1869, the lower classes in Norway were so poor that they could not afford washing equipment or towels (Sundt 1975/1869). Sundt's argumentation did not support the political interests, and the government did not allow him to continue his research, although his studies were of excellent quality (Christophersen 1975: X). This is an example of how important 
cleanliness was to politicians at that time. This period of economic upheaval was characterised by industrialisation, liberalism, free competition and growing inequalities between higher and lower classes (Nerbøvik 2004/1999: 20-94).

The Establishment hoped that clean streets, clean homes, and clean individuals would create moral, compliant, healthy, and productive members of society. The intension was to transform poor people through cleanliness. Poor people's cleanliness became a symbol of their moral stature and a guarantee of order. Doctors, nurses, and teachers had key roles in the major political work that was launched to encourage people to wash their houses, homes, and bodies according to hygiene guidelines (Nerbøvik 2004: 343-354, 385-392, Vigarello 1988: 191-198).

\section{As cheap as possible for society}

To improve cleanliness, public baths were built for the masses. However, experience from Paris shows that people were not allowed to bathe for more than 30 minutes, the temperature was set as low as was justifiable and automatic stop valves ensured that the baths were filled with the least possible amount of water. After a while it became too expensive to make bathing in bath tubs available to the poor. Showers were less expensive. An experiment with showers was carried out for the first time in a prison. After 1880, showers were installed as public bathing facilities in poor areas of Paris. Even less expensive was body wash with a washing barrel and a wash cloth, and detailed washing regulations were established on how to wash properly (Vigarello 1988: 79-122, 192-201, 215-225). This latter, least expensive, daily body wash, was recommended in nursing textbooks. Nightingale argued that everyone could keep clean, and that bathing was unnecessary. A jug of water and a rough towel were all that was needed (Nightingale 1997/1860: 136-138).

\section{Cleanliness in Post War nursing}

Until the Post War period hygiene seems to have functioned as a theoretical foundation for nursing in Norway. In 1967 there was a change. At that time a nursing textbook appeared in which the hygiene perspective was toned down to the advantage of humanistic need theory. The book starts with the statement that the aim 
of nursing is to attend to the basic needs of the sick and needy (Lerheim \& Norsk sykepleierforbund 1967).

\section{A need to take care of oneself}

It is clear that the textbook's argumentation on basic needs was inspired by the American nurse Virginia Henderson, whose ideas were spread worldwide by International Council of Nurses (ICN) in 1960. Henderson argues for 14 basic needs that nurses should take care of. One of these is helping patients keep their bodies clean and well groomed. Earlier, she writes, bed rest and bed bath were prescribed for days and weeks. This gave the patients a chance to talk, to tell the nurse about their troubles, and to feel the nurse's sympathy through touch. Now, Henderson writes in 1960, the pendulum has swung in the other direction. Physical and emotional dependency during illness is to be discouraged and replaced by activity. But nurses in overcrowded hospitals did not have time to engage in activities with patients, so the patients had to help themselves or be helped by relatively or totally untrained nurses. This was particularly true of provisions for cleanliness and elimination. Qualified nurses had taken over many of the physician's former functions and had become professionals who directed others on how to perform a service. That role made the daily, spontaneous communication with patients difficult. Henderson was worried that the hospitals would become cold and uncomfortable for patients who were unable to act as independently as expected (Henderson \& Norsk sykepleierforbund 1961/1960: 37-41).

Henderson seems inspired by the American humanistic psychologist Abraham Maslow. He argues for an active will in the human being for health and selfrealization. He developed his human need theory based on studies of people with a high degree of self-realization. Many of them had prominent positions in society (Hall \& Lindzey 1978: 266-275). Maslow's theory may have turned out quite differently had he studied very ill people.

Be clean, don't smell

Based on the need argumentation in the 1967 nursing textbook, we might expect that the needs of the patient were to determine how washing was to be performed. This 
connection, however, is not made in the mentioned textbook. Patients are expected to wash the greater part of their bodies at least once a day, and it appears as if the textbook attempts to adapt the human needs theory to fit such bodily washing practices (Lerheim \& Norsk sykepleierforbund 1967: 150). Those practices were in accordance with the norms established in the above mentioned textbook from 1911 (Waage 1911/1901).

\section{Humanistic legitimization}

How can it be that there was hardly any connection between the chapters that argue for nursing as a humanistic profession based on needs theory and the washing norms that were advocated in other chapters in the same textbook? Foucault argues that individuals in industrialised democracies have not only been controlled and formed by linking bodily practices to scientific knowledge, like hygiene theory above, but also by linking humanistic knowledge to politically expedient bodily practices (Foucault 1995/1976: 62-86). We consider Henderson's need theory a humanistic theory (Henderson \& Norsk sykepleierforbund 1961/1960). According to Foucault, such theories have been used to induce individuals to form themselves in accordance with society's expectations (Foucault 1995/1976: 28-46, 62-86). In the case of body washing, this would entail not asking for more help from society than absolutely necessary.

\section{Political context}

Henderson's need theory may have been used politically to legitimize the use of personnel with little or no education to care for the patients' bodies, so that nurses could concentrate on medical treatment and administration (Melby 1990: 202-208). That would have been very expedient in the Post-War period with its shortage of nurses. At that time much of the bodily nursing was transferred to nursing assistants with less education and lower wages. The Norwegian Nursing Association nurses disliked the change, as nurses lost much of the close contact they had had with patients. Bodily nursing had been considered a kind of treatment (Jervell 1944/1941a: V). The fact that Norwegian Nursing Association accepted the education of nursing assistants may have been rooted in the eagerness to establish nursing as a 
profession. In that respect it may have been an advantage to be associated more with medical treatment and to a lesser degree with bodily care. However, it may look as if the nursing profession used Henderson's humanistic needs theory to create a distance to the medical profession. This is understandable considering that a profession needs to establish itself as distinct from the neighbouring professions, and the nursing profession thus legitimized itself as a humanistic profession with distinct delineations to the scientific medical profession.

\section{Cleanliness in nursing today}

The daily bodily washing norms that were introduced in Norwegian nursing in 1911 are still practiced today. Observations and interviews in a Norwegian nursing home in 2002 and 2006 showed that patients washed their face, hands, mouth, chest, back, and private parts every day (Boge 2008: 99-159). The rest of the body was, with few exceptions, washed every 14.day when the patients were given a shower. There was little room for patients who wanted to shower more often, as that may increase the nursing home's costs. Neither was there room for patients who did not want to take showers or clean their teeth. Neither family, staff, nor other patients would accept untidy and smelly patients. Patients were usually showered every $14^{\text {th }}$ day independently of the needs they might have had. These practices were in close accordance with body wash practices in other Norwegian nursing homes and also with the minimum standard of washing in the most used textbook on nursing in Norway in the spring 2005 (Kristioffersen 1996/2004). Patients were not encouraged to wash themselves if it took more of the staff's time, i.e. was more expensive, than if nursing home personnel washed the patients. Self-care in the health sector only seems to be of interest if it reduces public expenses (Olsen 1998, Pols 2006).

The textbook uses both hygiene and need theory to legitimize nursing, while those who make political nursing decisions seem to be inspired by ideas from New Public Management (NPM). This philosophy takes as its starting point that the welfare state is too big and too expensive. In order to reduce costs the welfare state should operate more on the terms of the private sector. Initially, such arguments were used by more conservative politicians only, but the ideas have since been supported by social democrats (Hagen 2006: 205- 215). The NPM movement started in England around 1980. Up until then, bathing patients in need of care at home was considered 
a nursing service in England. It was not a service you paid for. In the 1990's, bathing that did not include medical treatment became a social service that individuals were required to pay for if possible, and bathing was to be carried out by persons who were not trained as nurses. Nursing was to be limited to medical treatment (Twigg 2000). Although those in need for help do not have to pay for body wash in Norway, the costs of community health services are kept as low as possible by using staff with little or no education to perform much of the bodily nursing work (Høst 2002, Dahle \& Isaksen 2000).

\section{Final remarks}

Political perspectives on bodily cleanliness in nursing challenge the scientific hygienic understandings of bodily cleanliness. That does not necessarily imply that hygiene is not important, but as far as we can see, the fear of miasmas and microbes cannot explain the bodily washing practices in Norwegian nursing textbooks and nursing homes. The political situation that made current washing practices in nursing emerge a hundred years ago, seems to lead us much closer to an answer to why bodily cleanliness practices in nursing are the way they are. Bodily cleanliness seems to have been a part of the political formation of a clean, pleasant smelling, decent, obedient, and productive population. Doctors, nurses, and teachers have played important roles in that bodily transformation work.

The self-help movement in nursing that emerged after the Second World War shows that not only scientific theory, but also humanistic theory can be used to legitimize politically interesting bodily cleanliness practices in nursing. At that time humanistic needs theories seem to have supported the political argumentation for as independent and self-aided patients as possible. Patients were expected to wash themselves if possible. Those who were not able to do so, should, as far as possible, be washed by cheaper staff with little or no education. Nurses should concentrate on medical treatment and professionalization.

The bodily washing practices in nursing in our time are in accordance with the norms of appearance and smell that emerged in the second part of the $19^{\text {th }}$ and the first part of the $20^{\text {th }}$ century. Staff with little or no education perform much of the bodily nursing work. Self-help only seems to be of interest when it reduces public expenses. In other 


\section{Nursing Philosophy}

words; bodily cleanliness in nursing does not seem to be based on the theories they lean on, but on a balance between politically expedient norms and economy. This politically interesting hygienic body wash routine was performed for health purposes only and not to promote well being. The patients I (first author) met in a ward at Churchill hospital some twenty years ago received a massage as part of the body wash routine purely for pleasure. Such practices for promoting well being constitute a break with the hygienic washing practices that arose in modern nursing some 150 years ago.

\section{References}

Boge, J. (2008) Kroppsvask i sjukepleia. Bergen University, Institutt for samfunnsmedisin, Seksjon for sykepleievitenskap.

Christophersen, H. O. (1975) Eilert Sundts studier av renslighetsstellet i Norge. I: Sundt, E. (red.) Om renslighets-stellet $i$ Norge, Oslo, Gyldendal.

Dahle, R. \& Isaksen, W., L. (2000) The silenced bodywork. I: Gannik, Effersøe, D. og Launsø, L. Disease, Knowledge ond Society, København, Samfundslitteratur.

Foucault, M. (1994) Question of Method. I: Faubion, J. D. (red.) Power, London, Penguin Books.

Foucault, M. (1995/1976) Seksualitetens historie 1. Viljen til viten, Oslo, Pax.

Foucault, M. (1999/1977) Overvåkning og straff., Oslo, Gyldendal.

Frykman, J. (1994) Hel og ren. I: Frykman, J. \& Löfgren, O. (red.) Det kultiverte menneske, Oslo, Pax Forlag.

Hagen, R. (2006) Nyliberalismen og samfunnsvitenskapene : refleksjonsteorier for det moderne samfunnet, Oslo, Universitetsforlaget.

Hall, C. S. \& Lindzey, G. (1978) Theories of personality, 3rd. utg. New York, Wiley.

Henderson, V. \& Norsk sykepleierforbund (1961/1960) ICN: sykepleiens grunnprinsipper, Oslo, Norsk sykepleierforbund.

Høst, H. (2002) Lærlingeordning eller skolebasert utdanning i pleie- og omsorgsfagene? Bergen

Jervell, A. (1944/1941a) Laerebok for sykepleiersker, bind I, 3.opplag. utg. Oslo, Fabritius \& Sønners Forlag. 
Kaurin, E. (1879) Sygepleiersken : kortfattet Veiledning i Sygepleien for Sygepleiersker i By og Bygd, Kristiania, Cammermeyer.

Kristioffersen, N. (1996/2004) Generell sykepleie, Oslo, Gyldendal Norsk Forlag.

Lerheim, K. \& Norsk sykepleierforbund (1967) Laerebok for sykepleieskoler, Bind I: generell sykepleieloere, Oslo, Fabritius \& Sønners Forlag.

Martinsen, K. (2003/1989) Omsorg, sykepleie og medisin: historisk-filosofiske essays, 2. utg. utg. Oslo, Universitetsforlaget.

Melby, K. (1990) Kall og kamp: Norsk sykepleierforbunds historie, Oslo, Norsk sykepleierforbund og J. W. Cappelens Forlag.

Moseng, O. G. (2003) Ansvaret for undersåttenes helse 1603-1850, Oslo, Universitetsforlaget.

Nerbøvik, J. (2004) Myndige møringar, 1740-1870, Oslo, Volda kommune i kommisjon hos Samlaget.

Nerbøvik, J. (2004/1999) Norsk historie 1860-1914: eit bondesamfunn i oppbrot, [Ny og utvidet utg.]. utg. Oslo, Samlaget.

Nightingale, F. (1997/1860) Notater om sykepleie, Revidert med tillegg, samlede utgaver. utg. Oslo, Universitetsforlaget.

Nissen, R. (2000/1877) Laerebog i Sygepleie for Diakonisser, 1.utg. utg. Oslo, Gyldendal.

Olsen, R. H. (1998) Klok av erfaring?: om sansning og oppmerksomhet, kunnskap og refleksjon i praktisk sykepleie, Oslo, Tano Aschehoug.

Pols, J. (2006) Washing the citizen: Washing, cleanliness and citizenship in mental health care. Culture, Medicine and Psychiatry, 30:77-104,

Schiøtz, A. (2003) Folkets helse - landets styrke. 1850-2003, Oslo, Universitetsforlaget.

Sundt, E. (1975/1869) Om renligheds-stellet i Norge, Oslo, Gyldendal.

Sydnes, T. (2001) Centrale ideer i Florence Nightingales sykepleiefilosofi. I: Birkelund, R. (red.) Omsorg, kald og kamp. Personer og ideer i sykepleiens historie, København, Gyldendal.

Twigg, J. (2000) Bathing, the body and community care, London, Routledge.

Vigarello, G. (1988) Concepts of Cleanliness:changing Attitudes in France since the Middle Ages, Cambridge, Cambridge University Press.

Waage, H. R. (1901) Laerebog i sygepleie, Kristiania, I kommisjon hos H. Aschehoug \& CO.

Waage, H. R. (1911/1901) Loerebok i sykepleie, 2. udg. utg. Kristiania, I kommisjon hos H. Aschehoug \& CO. 
1

2

3

4

5

6

7

8

9

10

11

12

13

14

15

16

17

18

19

20

21

22

23

24

25

26

27

28

29

30

31

32

33

34

35

36

37

38

39

40

41

42

43

44

45

46

47

48

49

50

51

52

53

54

55

56

57

58

59

60 